Arch. hist. jap. Vol. 20, n. 2 (August 1960).

P. 293-309.

Dept. of Radiol., Wakayama Med. College (Director: Prof. K. OGASAWARA).

\title{
Experimental Study on the Effects of X-ray on the Secretory Activity of the Gastric Chief Cells.
}

\begin{abstract}
X 線照射が背腺主細胞分泌機能に及ぼす影望に偹する実験的研究.
\end{abstract}
Tetsuya KUSUMOTO 楠本哲也。

(Received May 19, 1960.)

It is well known that the radiotoxemia and acute radiation syndrome manifested by weariness, anorexia, nausea and headache etc. are often observed during X-ray therapy. The mechanism whereby this syndrome occurs is still obscure though there are quite a few theories about it. Clinically, it is obvious that the most frequent symptom is referred to the stomach and that it is more easily induced when the epigastrium is irradiated more so than any other part of the body.

It has been proved that X-ray irradiation, even in small doses, generally causes damage of the tissue. The degree of the damage is different according to different tissue. A large dose of radiation, however, may be required for the complete collapse of the cell function. It may of ten occur that clinical manifestation of X-ray injury are not always associated with the observable histological changes. Especially in the glandular cells after irradiation by X-ray, there can often be observed a diminished function without any detectable morphological changes.

The author's experiments were carried out for the purpose of investigating the mechanism of the radiation syndrome especially as regards 1 . the effect of X-ray radiation given directly to the stomach on the secretory activity of the gastric gland cells, and 2. whether or not the same dose of radiation given to other parts of the body can also have the same effect on the gastric gland cells as in the former, because the stomach seems to be more susceptible to acute radiation syndrome than any other part of the body.

\section{Materials and Methods.}

Adult and male albino rats accustomed to a regular feeding of Mc COLLUM's artificial diet for a given period were used, and all the animals were unfed for 24 hrs. prior to the experiment.

Series A. Control.

An artificial diet was given. Samples were taken before and at periods of $\frac{1}{2}$, $1,2,3,6$ hrs. after the diet.

Series B. For the study on the effects of irradiation.

1. A single dose of $500 \mathrm{r}$ was irradiated on the epigastrium then, an hour later, the diet was given. Samples were taken at the same periods as in the controls.

2. A daily dose of $100 \mathrm{r}$ was irradiated on the epigastrium successively for 5 days before every feeding. Samples were taken before and after the last diet at the 
same periods as above.

3. A single dose of $500 \mathrm{r}$ was irradiated on the hypogastrium and the thigh then, an hour later, the diet was given.

4. A daily dose of $100 \mathrm{r}$ was irradiated successively for 5 days on the hypogastrium - the thigh then, an hour later, the diet was given.

5. Histamine dihydrochloride $0.3 \% 1 \mathrm{cc}$ was injected subcutaneously then, 5 min. later, a single dose of $500 \mathrm{r}$ was irradiated on the epigastrium. Samples were taken at the periods of $1 / 3,2 / 3,1,2,3 \mathrm{hrs}$. after the irradiation.

Series C. For study on the protective effects of some chemical agents against $\mathrm{X}$-ray injuries.

1. Prior to the irradiation of $500 \mathrm{r}$ on the epigastrium and to the diet, Polyvinylpyrrolidon (Pereston-N) $10 \mathrm{cc} / \mathrm{kg}$ weight was injected into the abdominal cavity. Viz. $5 \mathrm{~min}$. after the injection, X-ray was irradiated and, an hour after the irradiation, the diet was given. Samples were taken before and at periods of $\frac{1}{2}, 1,2,3$, $6 \mathrm{hrs}$. after the diet.

2. Thioctic acid $12.5 \mathrm{mg} / \mathrm{kg}$ weight was injected into the abdominal cavity prior to the administration of $\mathrm{X}$-ray and the diet.

3. 5-oxy-anthranilic acid $10 \mathrm{mg} / \mathrm{kg}$ weight and $100 \mathrm{mg} / \mathrm{kg}$ was injected into the abdominal cavity before the irradiation and the diet.

Throughout these experiments, the X-ray irradiation was conditioned as follows; the tube voltage being $180 \mathrm{KVp}$, tube current $15 \mathrm{~mA}$, filter $1.0 \mathrm{~mm} \mathrm{Cu}$ and $1.5 \mathrm{~mm}$ $\mathrm{Al}$, focal skin distance $400 \mathrm{~mm}$ and rate dose $52.9 \mathrm{r} / \mathrm{min}$. During the irradiation, the animals were lain on a back position and were enclosed in a $3 \mathrm{~mm}$ thick leaden cover with a hole of $35 \times 50 \mathrm{~mm}$. It was so arranged that the hole was over the epigastrium or the hypogastrium - the thigh.

To take samples, the thorax was opened under deep ether narcosis and, first, $2 \mathrm{cc}$ of blood was taken from the left heart ventricle for the determination of the histamine content in the blood using the NAKAMURA's method, SERA's diazoreaction and BECKMAN's spectrophotometer. Then secondly, LUNA's liquid was injected into all arteries through the left heart ventricle for the vital fixation. Small pieces were taken from the glandular portion of the stomach and they were placed in KOISTER's liquid for the post fixation. Paraffin sections of $4 \mu$ were made and stained by HEIDENHAIN's iron haematoxylin.

In series $\mathrm{C}$, the histamine in the blood was not measured for the reason that the agents used in this series may cause variable results.

\section{Observations.}

The gastric surface cells which secrete the gastric hormone productin (FUJIE) and the gastric chief cells whose function is supposed to be promoted by the said hormone and by histamine were observed.

The secretory functional figures of the chief cells observed morphologically were classified on the basis of FUJIE's method. The quantity of secretory granules and of secretory vacuoles in the chief cells were indicated by such marks as,+++++ , + ,,- . When the upper half of the cell body was full of secretory granules or 
vacuoles, it was marked +++ , and when no granules or no vacuoles could be seen, it was marked - . Three intervening steps of,,+++ \pm were made suitably between +++ and - . Besides these, the form of plastosomes and the aspect of the gland lumen were described to aid in ascertaining the function of the cells.

The activity of the surface cells was measured by the quantity of productin vacuoles in the subnuclear portion of the cells. A great number of the vacuoles and when the under half of the cell body was full of them was marked +++ or ++++ , no vacuoles was marked - . The intervening steps of,,+++ \pm were made suitably between +++ and - .

The results obtained were tabulated in Table $1-10$.

Table 1. Control. Administration of an artificial diet.

\begin{tabular}{|c|c|c|c|c|c|c|c|c|c|}
\hline \multirow{4}{*}{ 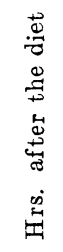 } & \multicolumn{5}{|c|}{ The chief cells } & \multirow{4}{*}{$\begin{array}{l}\text { Gland } \\
\text { lumen }\end{array}$} & \multirow{3}{*}{\multicolumn{2}{|c|}{$\begin{array}{l}\text { The productin } \\
\text { vacuoles in the } \\
\text { gastric surface } \\
\text { cells }\end{array}$}} & \multirow{4}{*}{ 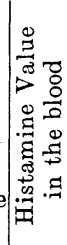 } \\
\hline & \multicolumn{3}{|c|}{ Total result } & \multirow{2}{*}{\multicolumn{2}{|c|}{$\begin{array}{l}\text { Representative } \\
\text { result }\end{array}$}} & & & & \\
\hline & \multicolumn{2}{|c|}{$\begin{array}{l}\text { Quantity of the } \\
\text { intracellular sec- } \\
\text { retory substance }\end{array}$} & \multirow{2}{*}{$\begin{array}{c}\text { Form of } \\
\text { pls. }\end{array}$} & & & & & & \\
\hline & $\begin{array}{c}\text { retory st } \\
\text { Granules }\end{array}$ & $\begin{array}{l}\text { ubstance } \\
\text { Vacuoles }\end{array}$ & & Granules & Vacuoles & & $\begin{array}{l}\text { Total } \\
\text { result }\end{array}$ & $\begin{array}{l}\text { sentative } \\
\text { result }\end{array}$ & \\
\hline $\begin{array}{l}\text { Be- } \\
\text { fore }\end{array}$ & $-\sim \pm$ & $-\sim \pm$ & $\begin{array}{l}\text { long rod, } \\
\text { short rod, } \\
\text { filament }\end{array}$ & $-\sim \pm$ & $-\sim \pm$ & narrow & $\begin{array}{l}-\sim \\
++++\end{array}$ & $\begin{array}{l}++\sim \\
++++\end{array}$ & 0.92 \\
\hline$\frac{1}{2}$ & $\pm \sim++$ & $\pm \sim+$ & $\begin{array}{l}\text { short rod, } \\
\text { guitar form, } \\
\text { long rod }\end{array}$ & + & $\pm \sim+$ & $\begin{array}{c}\text { narrow, } \\
\text { a little } \\
\text { wide }\end{array}$ & $\begin{array}{c}-\sim \\
+++\end{array}$ & $-\sim++$ & 1.31 \\
\hline 1 & $\stackrel{ \pm \sim}{+++}$ & $\stackrel{ \pm \sim}{+++}$ & $\begin{array}{l}\text { supra-short } \\
\text { rod, short } \\
\text { rod, guitar } \\
\text { form, long }\end{array}$ & $\begin{array}{l}++\sim \\
+++ \\
+\sim++ \\
\pm \sim+\end{array}$ & $\begin{array}{l} \pm \sim+ \\
+\sim++ \\
+++\end{array}$ & $\begin{array}{l}\text { wide, } \\
\text { a little } \\
\text { wide }\end{array}$ & $\begin{array}{l}-\sim \\
++(+)\end{array}$ & $-\sim+$ & 1.45 \\
\hline 2 & $\begin{array}{l} \pm \sim++ \\
++t\end{array}$ & $\stackrel{+\sim}{++}$ & $\begin{array}{c}\text { rod } \\
\text { short rod, } \\
\text { supra-short } \\
\text { rod, guitar } \\
\text { form, long } \\
\text { rod, rosary } \\
\text { form }\end{array}$ & $\pm \sim++$ & $+\underset{++}{\sim}$ & $\begin{array}{l}\text { wide, } \\
\text { a little } \\
\text { wide }\end{array}$ & $-\tilde{+}++$ & $\stackrel{ \pm \sim(+)}{\sim}$ & 1.00 \\
\hline 3 & $\pm \sim++$ & $\pm \sim++$ & $\begin{array}{l}\text { short rod, } \\
\text { long rod, } \\
\text { guitar form }\end{array}$ & $\underset{+(+)}{ \pm \sim}$ & $\pm \sim++$ & $\begin{array}{c}\text { a little } \\
\text { wide }\end{array}$ & $\begin{array}{c}-\sim \\
+++\end{array}$ & $\stackrel{+\sim}{++}+$ & 0.65 \\
\hline 6 & $\pm \sim+$ & $-\sim+$ & $\begin{array}{l}\text { long rod, } \\
\text { short rod, } \\
\text { rosary form }\end{array}$ & $\pm \sim+$ & $( \pm) \sim+$ & $\begin{array}{l}\text { narrow, } \\
\text { a little } \\
\text { wide }\end{array}$ & $\begin{array}{l}+\sim \\
++++\end{array}$ & $+\underset{+}{+}+$ & 0.84 \\
\hline
\end{tabular}

Table 2. A single dose of $500 \mathrm{r}$ was irradiated on the epigastrium, then the diet was given.

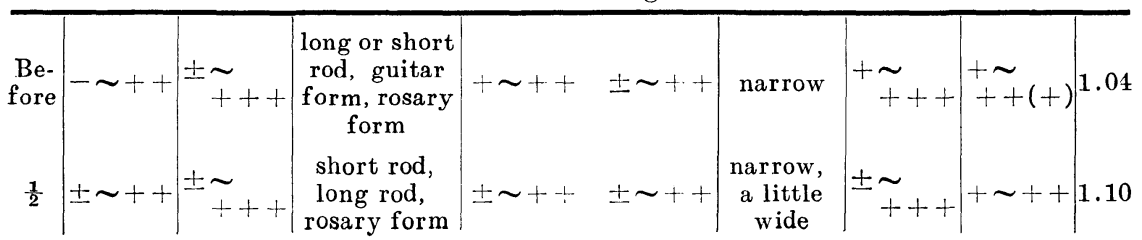






Table 3. Daily $100 \mathrm{r}$ was irradiated on the epigastrium for 5 days. An hour after the last radiation the diet was given.

\begin{tabular}{|c|c|c|c|c|c|c|c|c|c|}
\hline \multirow{5}{*}{ 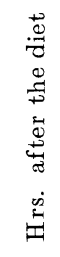 } & \multicolumn{5}{|c|}{ The chief cells } & \multirow{5}{*}{$\begin{array}{l}\text { Gland } \\
\text { lumen }\end{array}$} & \multirow{3}{*}{\multicolumn{2}{|c|}{$\begin{array}{l}\text { The productin } \\
\text { vacuoles in the } \\
\text { gastric surface } \\
\text { cells }\end{array}$}} & \multirow{5}{*}{ 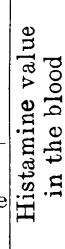 } \\
\hline & \multicolumn{3}{|c|}{ Total result } & \multirow{3}{*}{\multicolumn{2}{|c|}{$\begin{array}{l}\text { Representative } \\
\text { result }\end{array}$}} & & & & \\
\hline & \multirow{2}{*}{\multicolumn{2}{|c|}{$\begin{array}{l}\text { Quantity of the } \\
\text { intracellular sec- } \\
\text { retory substance }\end{array}$}} & \multirow{3}{*}{$\begin{array}{l}\text { Form of } \\
\text { pls. }\end{array}$} & & & & & & \\
\hline & & & & & & & Total & Repre- & \\
\hline & Granules & Vacuoles & & Granules & Vacuoles & & & result & \\
\hline $\begin{array}{l}\text { Be- } \\
\text { fore }\end{array}$ & $-\sim++$ & $\pm \sim++$ & $\begin{array}{l}\text { short rod, } \\
\text { long rod, } \\
\text { rosary form }\end{array}$ & $+\sim++$ & $\stackrel{ \pm \sim(+)}{\sim}$ & $\begin{array}{l}\text { a little } \\
\text { wide, } \\
\text { narrow }\end{array}$ & $\stackrel{+\sim}{+++}$ & $\stackrel{+\sim}{+++}$ & 1.40 \\
\hline$\frac{1}{2}$ & $\pm \sim++$ & $\frac{ \pm \sim}{+++}$ & $\begin{array}{l}\text { short rod, } \\
\text { guitar form, } \\
\text { rosary form, } \\
\text { long rod }\end{array}$ & $\pm \underset{+(+)}{ \pm}$ & $+\underset{+}{+}+$ & $\begin{array}{c}\text { a little } \\
\text { wide }\end{array}$ & $\stackrel{-\sim}{++}$ & $\pm \sim++$ & 0.97 \\
\hline 1 & $-\sim++$ & $\begin{array}{l} \pm \sim \\
+++\end{array}$ & $\begin{array}{l}\text { short rod, } \\
\text { guitar form, } \\
\text { supra-short } \\
\text { rod }\end{array}$ & $\pm \sim++$ & $\stackrel{ \pm \sim}{+++}$ & $\begin{array}{c}\text { a little } \\
\text { wide }\end{array}$ & $\frac{-\sim}{++(+)}$ & $-\widetilde{+}(+)$ & 1.30 \\
\hline 2 & $-\sim(+)$ & $-\sim+\dot{+}$ & $\begin{array}{l}\text { short or long } \\
\text { rod, rosary } \\
\text { form, guitar } \\
\text { form }\end{array}$ & $\stackrel{+}{+}+(+)$ & $\pm \sim++$ & $\begin{array}{c}\text { a little } \\
\text { wide }\end{array}$ & $-\underset{+}{-\sim+}$ & 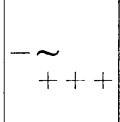 & 0.77 \\
\hline 3 & $-\sim++$ & $-\sim++$ & $\begin{array}{l}\text { short rod, } \\
\text { long rod, } \\
\text { rosary form }\end{array}$ & $+\sim++$ & $\pm \sim++$ & $\begin{array}{l}\text { a little } \\
\text { wide, } \\
\text { wide }\end{array}$ & $\stackrel{ \pm \sim++}{+}$ & 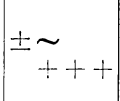 & 1.00 \\
\hline 6 & $-\sim++$ & $\begin{array}{c}-\sim \\
+++\end{array}$ & $\begin{array}{l}\text { long rod, } \\
\text { short rod, } \\
\text { rosary form }\end{array}$ & $\pm \sim++$ & $\frac{ \pm \sim}{++(+)}$ & $\begin{array}{l}\text { a little } \\
\text { wide }\end{array}$ & $\stackrel{ \pm \sim}{+++}$ & $\stackrel{+}{+}++$ & 0.93 \\
\hline
\end{tabular}

Table 4. A single dose of $500 \mathrm{r}$ was irradiated on the hypogastrium-the thigh. An hour later, the diet was given.

\begin{tabular}{|c|c|c|c|c|c|c|c|c|}
\hline $\begin{array}{l}\text { Be- } \\
\text { fore }\end{array}$ & $\begin{array}{c}+\sim \\
+++\end{array}$ & $\pm \sim(+)$ & $\begin{array}{l}\text { short rod, } \\
\text { guitar form, } \\
\text { rosary form, } \\
\text { long rod }\end{array}$ & $+\sim++\quad \pm \sim+$ & $\begin{array}{l}\text { a little } \\
\text { wide, } \\
\text { narrow }\end{array}$ & $\underset{++t}{\sim}$ & $\stackrel{ \pm \sim}{+++}$ & 0.87 \\
\hline
\end{tabular}




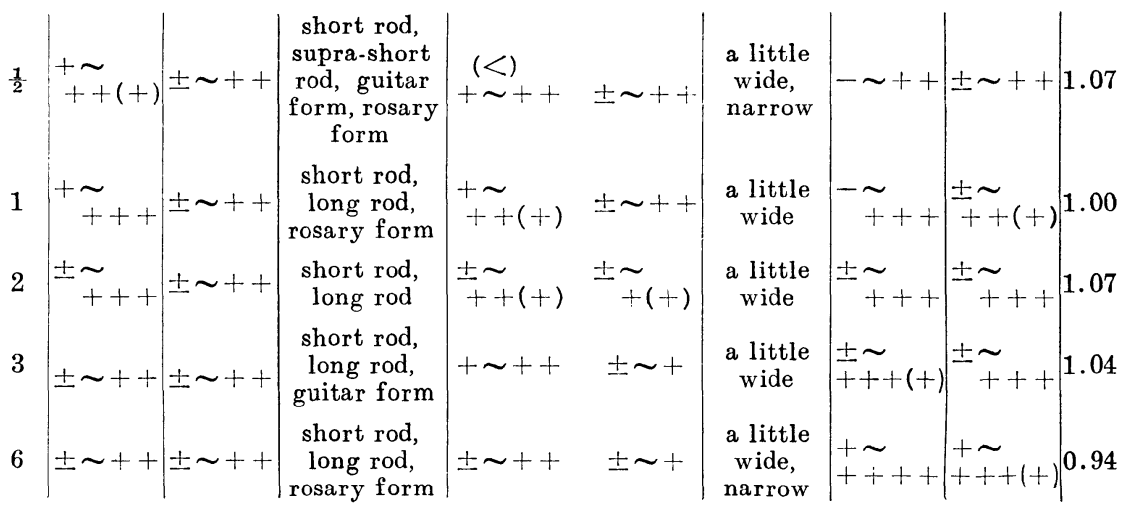

Table 5. Daily $100 \mathrm{r}$ was irradiated for 5 days on the hypogastrium - the thigh. An hour after the irradiation diet was given.

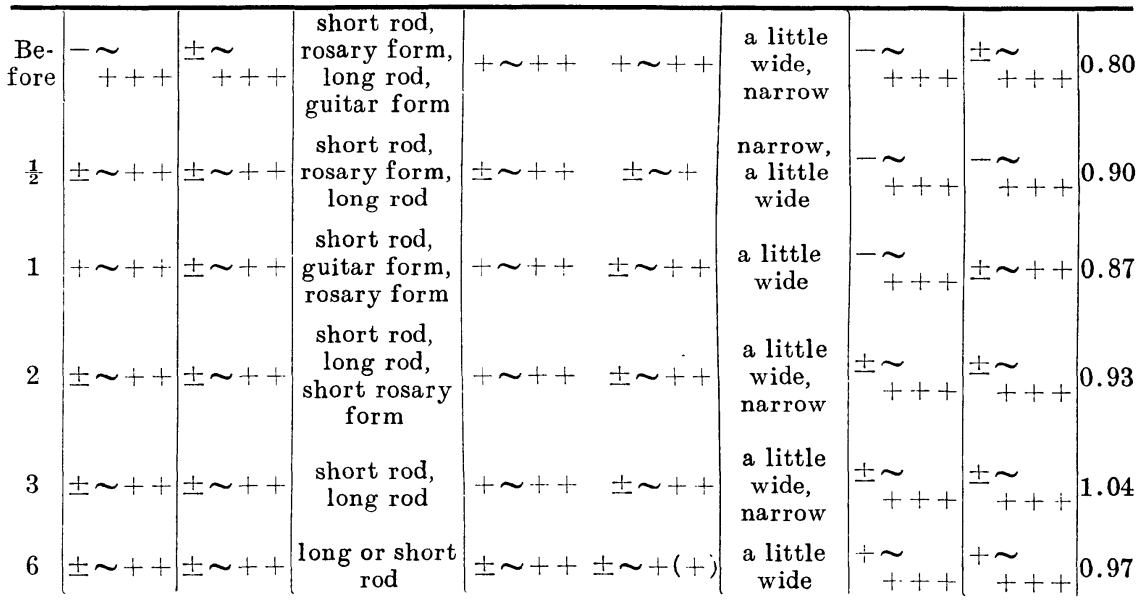

Table 6. Histamine was injected subcutaneously, 5 min. later, $500 \mathrm{r}$ was irradiated on the epigastrium.

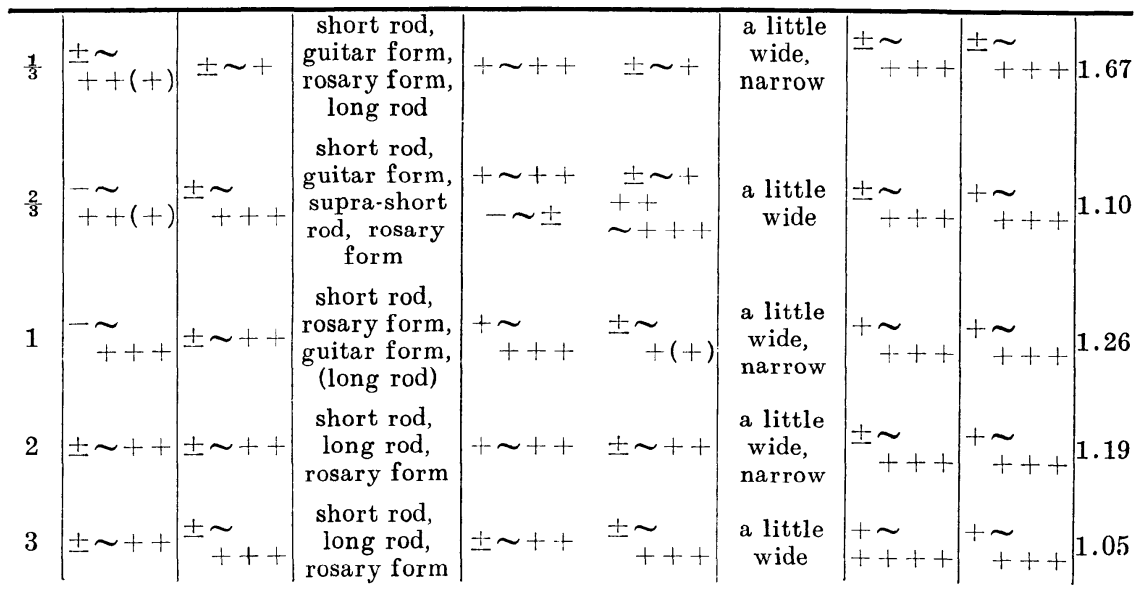


Table 7. Polyvinylpyrrolidon was injected into the abdominal cavity. 5 min. later, $500 \mathrm{r}$ was irradiated on the epigastrium then, $1 \mathrm{hr}$. later, the diet was given.

\begin{tabular}{|c|c|c|c|c|c|c|c|c|}
\hline \multirow{5}{*}{ 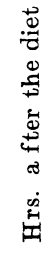 } & \multicolumn{5}{|c|}{ The chief cells } & \multirow{5}{*}{$\begin{array}{l}\text { Gland } \\
\text { lumen }\end{array}$} & \multirow{3}{*}{\multicolumn{2}{|c|}{$\begin{array}{l}\text { The productin } \\
\text { vacuoles in the } \\
\text { gastric surface } \\
\text { cells }\end{array}$}} \\
\hline & \multicolumn{3}{|c|}{ Total result } & \multirow{3}{*}{\multicolumn{2}{|c|}{$\begin{array}{l}\text { Representative } \\
\text { result }\end{array}$}} & & & \\
\hline & \multirow{2}{*}{\multicolumn{2}{|c|}{$\begin{array}{l}\text { Quantity of the } \\
\text { intracellular sec- } \\
\text { retory substance }\end{array}$}} & \multirow{3}{*}{$\begin{array}{l}\text { Form of } \\
\text { pls. }\end{array}$} & & & & & \\
\hline & & & & & & & \multirow{2}{*}{$\begin{array}{l}\text { Total } \\
\text { result }\end{array}$} & \multirow{2}{*}{$\begin{array}{l}\text { Represen- } \\
\text { tative } \\
\text { result }\end{array}$} \\
\hline & Granules & Vacuoles & & Granules & Vacuoles & & & \\
\hline $\begin{array}{l}\text { Be- } \\
\text { fore }\end{array}$ & $\pm \sim++$ & $\pm \sim++$ & $\begin{array}{l}\text { short rod, } \\
\text { long rod, } \\
\text { guitar form, } \\
\text { supra-short } \\
\text { rod }\end{array}$ & $+\sim++$ & $\pm \sim+$ & $\begin{array}{l}\text { a little } \\
\text { wide, } \\
\text { (narrow) }\end{array}$ & $-\sim+++$ & $\pm \sim+++$ \\
\hline$\frac{1}{2}$ & $\pm \sim+t$ & $\pm \sim+$ & $\begin{array}{l}\text { short rod, } \\
\text { supra-short } \\
\text { rod, guitar } \\
\text { form, rosary } \\
\text { form }\end{array}$ & $+\sim++$ & $\pm \sim+$ & $\begin{array}{l}\text { a little } \\
\text { wide, } \\
\text { narrow }\end{array}$ & $\stackrel{-\sim}{++(+)}$ & $\stackrel{-\sim}{++(+)}$ \\
\hline 1 & $\pm \sim++$ & $\pm \sim++$ & $\begin{array}{l}\text { short rod, } \\
\text { short rosary } \\
\text { form, guitar } \\
\text { form, rosary } \\
\text { form }\end{array}$ & $+\sim++$ & $\pm \sim++$ & $\begin{array}{l}\text { a little } \\
\text { wide, } \\
\text { narrow }\end{array}$ & $\stackrel{-\sim}{++(+)}$ & $\pm \sim++$ \\
\hline 2 & $-\sim++$ & $\pm \sim++$ & $\begin{array}{l}\text { short rod, } \\
\text { long rod, } \\
\text { rosary form, } \\
\text { guitar form }\end{array}$ & $\pm \sim++$ & $\pm \sim++$ & $\begin{array}{l}\text { a little } \\
\text { wide, } \\
\text { (wide) }\end{array}$ & $-\sim+++$ & $\pm \sim+++$ \\
\hline 3 & $-\sim++$ & $\pm \sim++$ & $\begin{array}{l}\text { short rod, } \\
\text { long rod, } \\
\text { guitar form, } \\
\text { rosary form }\end{array}$ & $\pm \sim++$ & $\pm \sim++$ & $\begin{array}{l}\text { a little } \\
\text { wide, } \\
\text { wide }\end{array}$ & $\pm \sim+++$ & $+\sim+++$ \\
\hline 6 & $-\sim++$ & $\pm \sim++$ & $\begin{array}{c}\text { long rod, } \\
\text { short rod, } \\
\text { rosary form }\end{array}$ & $\frac{ \pm \sim(+)}{+(+)}$ & $+\sim++$ & $\begin{array}{l}\text { a little } \\
\text { wide }\end{array}$ & $\pm \sim+++$ & $\pm \sim+++$ \\
\hline
\end{tabular}

Table 8. Thioctic acid was injected into the abdominal cavity. 5 min. later, $500 \mathrm{r}$ was irradiated on the epigastrium then $1 \mathrm{hr}$. later, the diet was given.

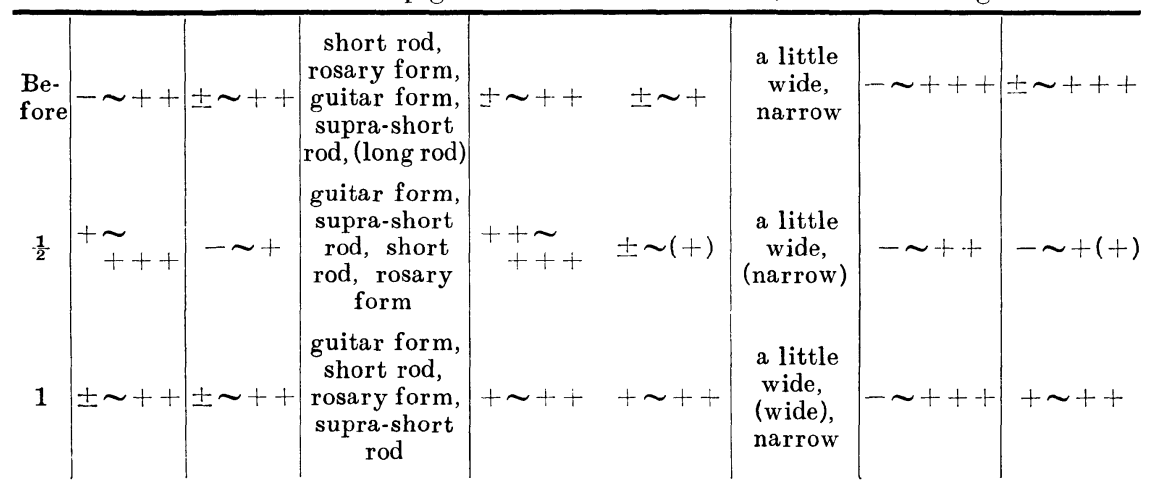




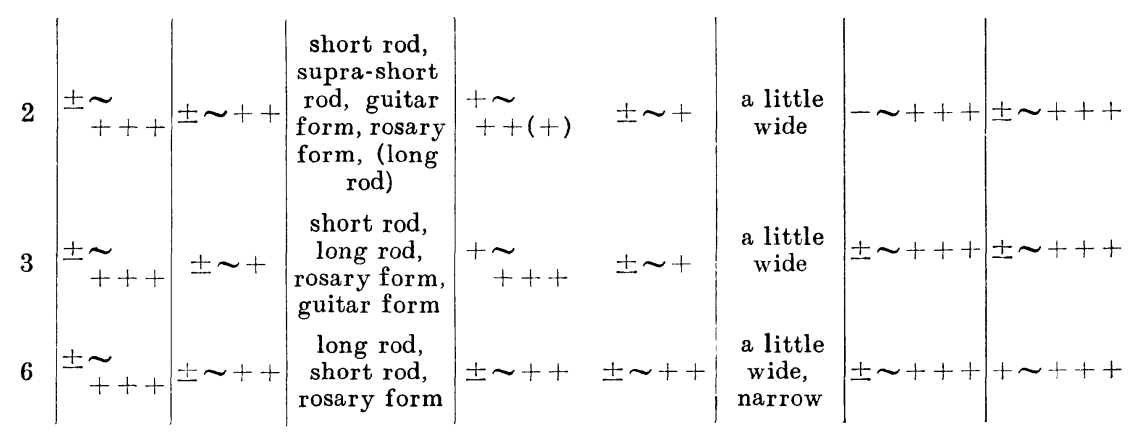

Table 9. 5-oxy-anthranilic acid $10 \mathrm{mg} / \mathrm{kg}$ was injected into the abdominal cavity. $5 \mathrm{~min}$. later, $500 \mathrm{r}$ was irradiated on the epigastrium then, $1 \mathrm{hr}$.

later, the diet was given.



Table 10. 5-oxy-anthranilic acid $100 \mathrm{mg} / \mathrm{kg}$ was injected into the abdominal cavity. $5 \mathrm{~min}$. later, $500 \mathrm{r}$ was irradiated on the epigastrium then, $1 \mathrm{hr}$. later, the diet was given.

\begin{tabular}{|c|c|c|c|c|c|c|c|c|}
\hline $\begin{array}{l}\mathrm{Be}- \\
\text { fore }\end{array}$ & $-\sim+$ & $\pm \sim+$ & $\begin{array}{l}\text { short rod, } \\
\text { long rod, } \\
\text { rosary form, } \\
\text { guitar form }\end{array}$ & $\pm \sim+$ & $\pm \sim+$ & $\begin{array}{l}\text { a little } \\
\text { wide, } \\
\text { narrow }\end{array}$ & $\pm \sim+++$ & $\pm \sim+++$ \\
\hline$\frac{1}{2}$ & $\pm \sim++$ & $\pm \sim++$ & $\begin{array}{l}\text { short rod, } \\
\text { rosary form, } \\
\text { long rod, } \\
\text { guitar form }\end{array}$ & $+\sim+\frac{1}{1}$ & $\pm \sim++$ & $\begin{array}{l}\text { a little } \\
\text { wide, } \\
\text { narrow }\end{array}$ & $-\sim+++$ & $\pm \sim++$ \\
\hline 1 & $\pm \sim++$ & $\pm \sim++$ & $\begin{array}{l}\text { short rod, } \\
\text { rosary form, } \\
\text { long rod, } \\
\text { guitar form }\end{array}$ & $\pm \sim++$ & $\pm \sim++$ & $\begin{array}{l}\text { a little } \\
\text { wide, } \\
\text { wide }\end{array}$ & $-\sim+++$ & $\begin{array}{l} \pm \sim \\
++(+)\end{array}$ \\
\hline
\end{tabular}




\begin{tabular}{|c|c|c|c|c|c|c|c|c|}
\hline \multirow{5}{*}{ 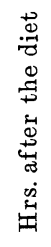 } & \multicolumn{5}{|c|}{ The chief cells } & \multirow{5}{*}{$\begin{array}{l}\text { Gland } \\
\text { lumen }\end{array}$} & \multirow{3}{*}{\multicolumn{2}{|c|}{$\begin{array}{l}\text { The productin } \\
\text { vacuoles in the } \\
\text { gastric surface } \\
\text { cells }\end{array}$}} \\
\hline & \multicolumn{3}{|c|}{ Total result } & \multirow{3}{*}{\multicolumn{2}{|c|}{$\begin{array}{l}\text { Representative } \\
\text { result }\end{array}$}} & & & \\
\hline & \multirow{2}{*}{\multicolumn{2}{|c|}{$\begin{array}{l}\text { Quantity of the } \\
\text { intracellular sec- } \\
\text { retory substance }\end{array}$}} & \multirow{3}{*}{$\begin{array}{l}\text { Form of } \\
\text { pls. }\end{array}$} & & & & & \\
\hline & & & & & & & \multirow{2}{*}{$\begin{array}{l}\text { Total } \\
\text { result }\end{array}$} & \multirow{2}{*}{$\begin{array}{l}\text { Represen- } \\
\text { tative } \\
\text { result }\end{array}$} \\
\hline & Granules & Vacuoles & & Granules & Vacuoles & & & \\
\hline 2 & $\stackrel{-\sim}{++}$ & $\begin{array}{l} \pm \sim \\
+++\end{array}$ & $\begin{array}{l}\text { long rod, } \\
\text { rosary form, } \\
\text { short rod }\end{array}$ & $\begin{array}{l}++\sim \\
+++ \\
-\sim \pm\end{array}$ & $\left.\begin{array}{c} \pm \sim+ \\
++\sim \\
+++\end{array}\right)$ & $\begin{array}{l}\text { wide, } \\
\text { a little } \\
\text { wide }\end{array}$ & $-\sim+++$ & $-\sim+++$ \\
\hline 3 & $\stackrel{-\sim}{+}+$ & $\stackrel{ \pm \sim}{+++}$ & $\begin{array}{l}\text { long rod, } \\
\text { short rod, } \\
\text { rosary form }\end{array}$ & $\begin{array}{l}++\sim \\
+++ \\
(-\sim \pm\end{array}$ & $\left.\begin{array}{c} \pm \sim+ \\
++\sim \\
+++\end{array}\right)$ & $\begin{array}{l}\text { a little } \\
\text { wide, } \\
\text { wide }\end{array}$ & $\pm \sim+++$ & $+\sim+++$ \\
\hline 6 & $-\sim$ & $\pm \sim++$ & $\begin{array}{l}\text { long rod, } \\
\text { short rod, } \\
\text { rosary form }\end{array}$ & $\stackrel{ \pm \sim}{+++}$ & $\pm \sim++$ & $\begin{array}{l}\text { a little } \\
\text { wide, } \\
\text { wide }\end{array}$ & $\pm \sim+++$ & $\pm \sim-1++$ \\
\hline
\end{tabular}

\section{Discussion.}

For the sake of convenience, the representative results of the quantity of the

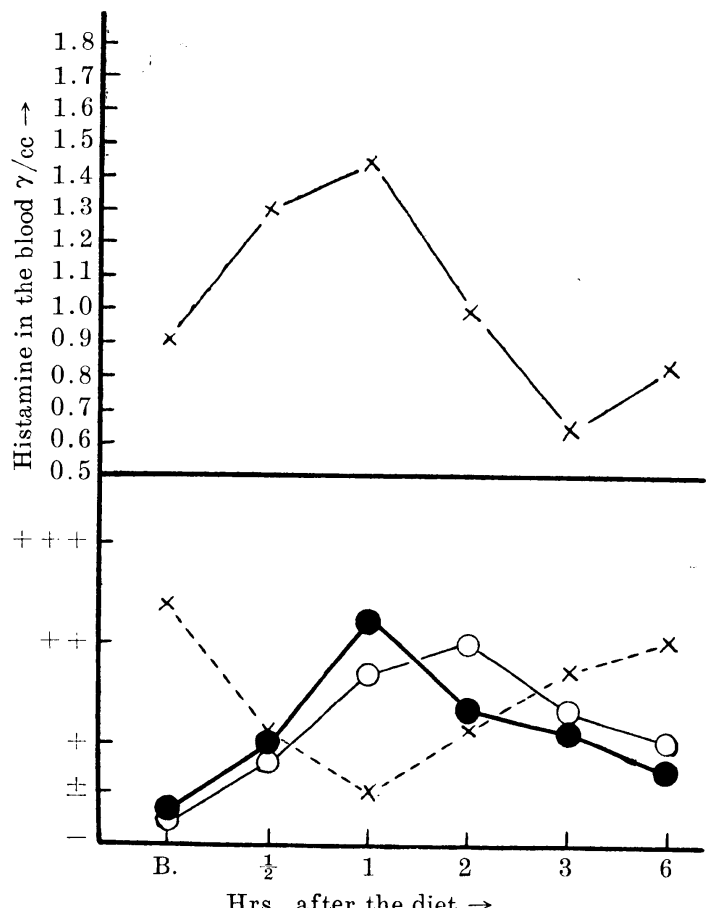

Secretory granules $(\mathbf{O})$, secretory vacuoles $(\bigcirc)$ in the chief cells, productin vacuoles $(X)$ in the surface cells. B : Before administration of the diet.

Fig. 1. Control. Administration of an artificial diet. 
secretory substance in the chief cells, of the productin vacuoles in the surface cells, and of the value of histamine in the blood were summarized in the same figure.

In the control animals (Table 1, Fig. 1), the secretory granules of the chief cells are produced soon after the diet and then vacuolized and excreted from the cells. Productin vacuoles in the surface cells decrease temporarily after the diet and then increase again in the cells. Histamine in the blood is found to be the reverse of the quantity of productin vacuoles in the surface cells.

In the animals receiving a single dose of $500 \mathrm{r}$ on the epigastrium an hour before the diet, a moderate production of secretory granules in the chief cells, slightly less productin vacuoles in the surface cells and a low histamine content in the blood can be seen before the diet. $\frac{1}{2}$ and $1 \mathrm{hr}$. after the diet, a decrease of productin vacuoles in the surface cells and a slight increase of histamine in the blood is noted, while the number of secretory granules and vacuoles in the chief cells remains unchanged. 2-6 hrs. after the diet, an increase of productin vacuoles in the surface cells and a decrease of histamine in the blood are noticed (Table 2, Fig. 2).



Fig. 2. A single dose of $500 \mathrm{r}$ was irradiated on the epigastrium. $1 \mathrm{hr}$. later, the diet was given.

From these results, it will be noticed as a result of the $500 \mathrm{r}$ irradiation that 1. discharge of productin from the surface cells is mildly supressed, 2. the increase of histamine in the blood is intensely inhibited and 3. the production of secretory granules and vacuolization (discharge) of them in the chief cells are slowed up. 
In the case of animals receiving the same dose of radiation on the hypogastrium - the thigh, discharge of productin vacuoles from the surface cells is similar to the former, but histamine in the blood and secretory granules in the chief cells are a little more than in the former (Table 4, Fig. 3). Comparing these two series with

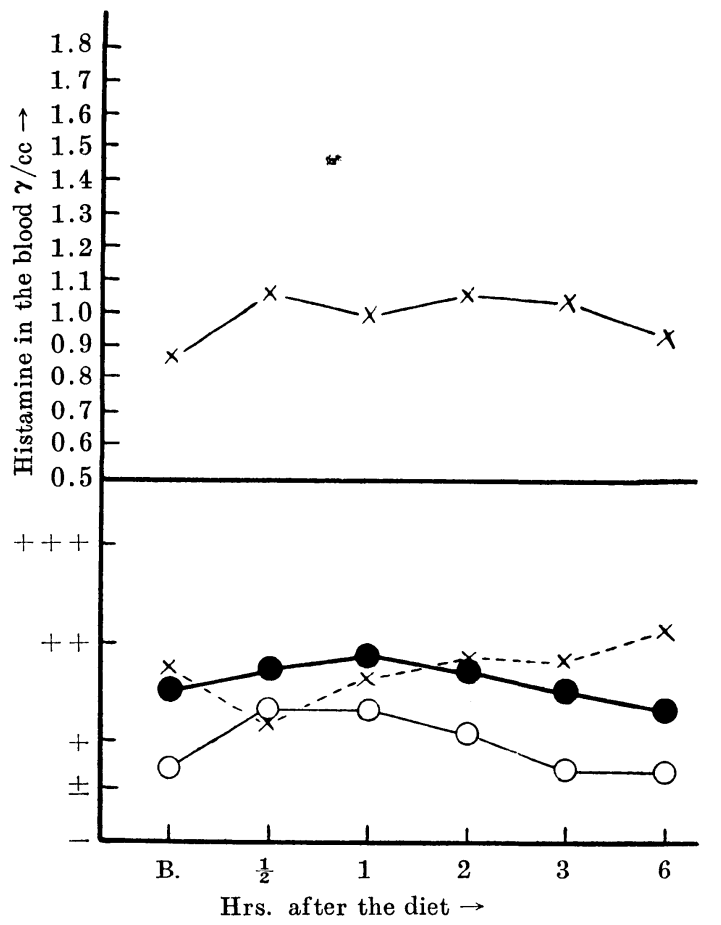

Fig. 3. A single dose of $500 \mathrm{r}$ was irradiated on the hypogastriumthe thigh. $1 \mathrm{hr}$. later, the diet was given.

the control (Fig. 1), however, the differences between the irradiation on the epigastrium (Fig. 2) and on the hypogastrium - the thigh (Fig. 3) are almostneg ligible, and it can be said that there is an identical tendency in both case.

In the case of animals receiving prolonged irradiation of $100 \mathrm{r}$ daily on the epigastrium for 5 days, the output of productin before and after the diet is no different from the case of a single irradiation of $500 \mathrm{r}$ but secretory vacuoles increase in the chief cells after the diet (Table 3, Fig. 4). This finding will suggest that the active production of secretory granules has already been initiated in the cells, because the secretory vacuoles were produced by the vacuolization of the granules. Histamine values of the blood in this case are unexplainably different according to different periods after the diet.

In the series of animals receiving prolonged irradiation on the hypogastriumthe thigh (Table 5, Fig. 5), peptic secretory granules and vacuoles are a little more numerous than in the case of a single irradiation of $500 \mathrm{r}$ on the same area. There are, however, no observable changes in the output of productin vacuoles and hista- 
Fig. 4. $100 \mathrm{r}$ pro die was irradiated on the epigastrium for 5 days. $1 \mathrm{hr}$. later, the diet was given.
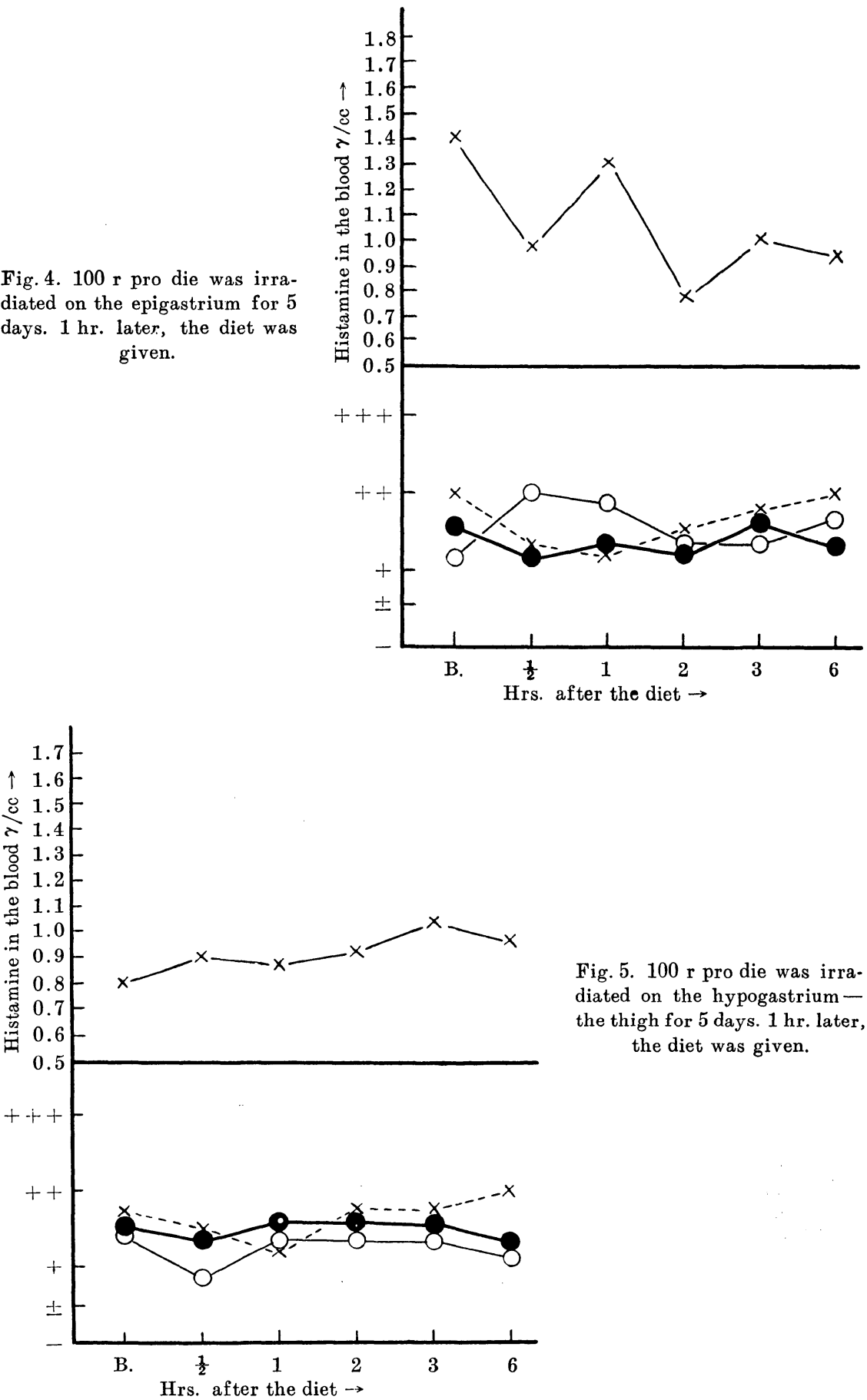

Fig. 5. $100 \mathrm{r}$ pro die was irradiated on the hypogastrium the thigh for 5 days. 1 hr. later, the diet was given. 
mine in the blood.

These results obtained from the above 4 series of experiments reveal many noticeable findings. Viz. the X-ray radiation prior to the diet brings about a mild supression of productin discharge from the surface cells, a reduced production and vacuolization of peptic secretory granules in the chief cells and a low histamine content in the blood, independently of the X-ray dosage and the exposed areas. On the other hand, comparing the case of a single irradiation of $500 \mathrm{r}$ with the case of a divided irradiation of $100 \mathrm{r}$ pro die for 5 days, both secretory granules and vacuoles in the chief cells are a little more numerous in the latter case than in the former. The author tries to explain these results using the productin theory of FUJIE. The gastric hormone productin of FUJIE is histamine-like and promotes production of secretory granules in the chief cells. The decomposed product of productin promotes the vacuolization (discharge) of the granules. The results obtained from the $500 \mathrm{r}$ irradiation on the epigastrium prove that the effects of productin and of the decomposed product of it on the secretory activity of the gastric chief cells are less, while there seems to be a sufficient secretion of the hormone to stimulate the cell function. Here, perhaps the reason may be the injury of the chief cells by X-ray. However, an unusually low histamine content in the blood as compared with the discharge of productin and the same tendency of the chief cells as when $500 \mathrm{r}$ was irradiated on the hypogastrium - the thigh, can not be attributed to this cause.



Fig. 6. Histamine was injected subcutaneously, 5min. later, $500 \mathrm{r}$ was irradiated on the epigastrium. 
There is also a possibility that an inactivation of the productin which promotes the secretory activity of the chief cells may occur. If a certain substance is produced in the tissue irradiated and the substance inactivates productin, it may be that the secretory activity of the gastric chief cells is lowered wherever the exposed areas may be, and that the histamine content in the blood is lowered more than the discharge of productin.

MAYAMA reported that the auto-antibody produced in the tissue by the X-ray irradiation causes low acidity of the gastric juice and inhibited secretion of it. HIRATA has reported, in accordance with the former, that an antigen-antibody reaction with an auto-antibody formed in the tissue is responsible for the radiation sickness. These findings support the author's contention that a certain substance produced in the tissue after the irradiation of X-ray may inhibit the action of the gastric hormone productin.

In order to confirm this, histamine which has an identical action with Productin, was tested prior the radiation of X-ray on the epigastrium (Table 6, Fig. 6) and the results were compared with those reported by SHIMIZU concerning the effects of histamine on the chief cells (Fig. 7). It is noticed in this case that secretory granules in the chief cells are not numerous, while secretory vacuoles are numerous and that histamine in the blood, increased by histamine injection, decreases speedy. Viz. the effect of histamine injected on the chief cells is less, while the effect of the

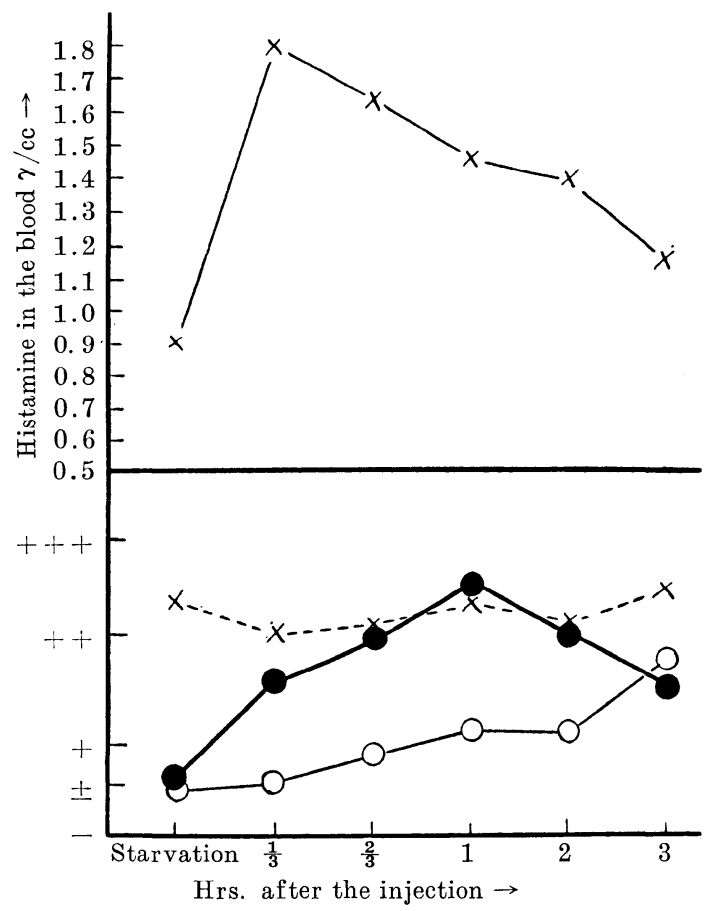

Fig. 7. Histamine was injected subcutaneously into normal rats. (Referred to the result of SHIMIZU). 
decomposed product of histamine is dominant. These results will confirm the author's contention mentioned above.

In the next experiment, some chemical agents which are probably protective against clinical X-ray injuries, were tested to ascertain if they can decrease the inhibitive effect of X-ray on the secretory activity of the chief cells (Table 7-10, Fig. 8 -11). The author used three agents as follows; viz. 1. polyvinylpyrrolidon (pereston-N), a high molecular compound and a detoxicant, 2. thioctic acid, a preventer of the oxidation of sulfhydryl group $(\mathrm{SH})$ and 3. 5-oxy-anthranilic acid, a reducing agent (NAKAMURA).

As shown in the figures, the effects of these agents against the $\mathrm{X}$-ray injury are all different and none of these can prevent completely the effects of X-ray on the chief cells. Polyvinylpyrrolidon can prevent to a slight extent the controlled vacuolization of secretory granules in the chief cells (Fig. 8). The administration of thioctic acid (Fig. 9) and $100 \mathrm{mg} / \mathrm{kg}$ of 5-oxy-anthranilic acid (Fig. 11) can exclude the suppressed production of secretory granules in the chief cells but can not promote the vacuolization of the granules. Here it is noticed that thioctic acid and $100 \mathrm{mg} / \mathrm{kg}$ of 5-oxy-anthranilic acid are effective in preventing the inhibitory action of the substance, which may be produced in the tissue by the X-ray irradiation, on the productin though they seem not to be effective on the promotion of the gastric secretion, because they do not cause the vacuolization of the peptic granules in the chief cells. When $10 \mathrm{mg} / \mathrm{kg}$ of 5 -oxy-anthranilic acid is administered (Fig. 10), the inhibi-

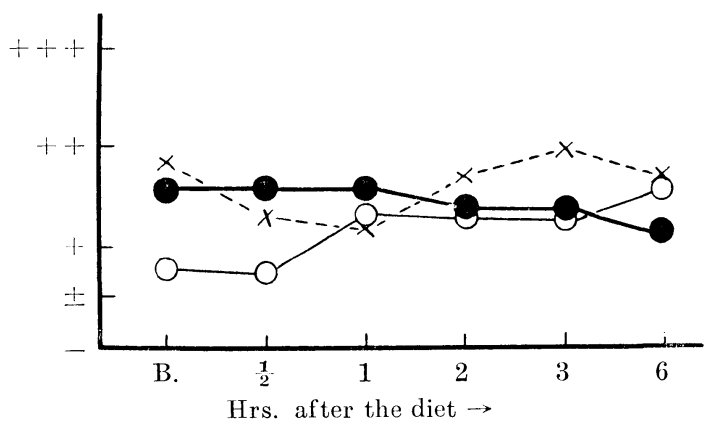

Fig. 8. Polyvinylpyrrolidon was injected prior to the X-ray and the diet.

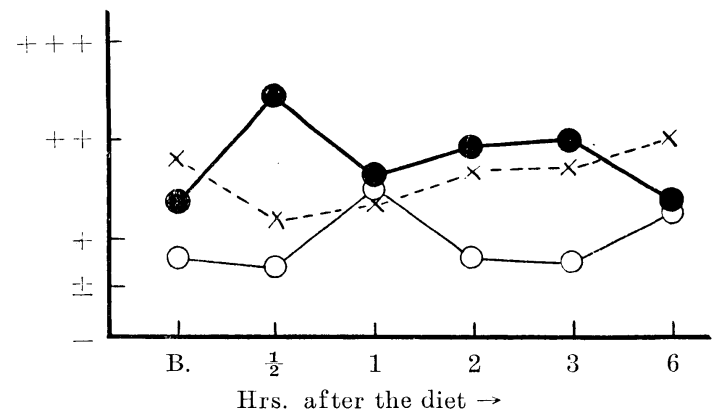

Fig. 9. Thioctic acid was injected prior to the X-ray and the diet. 




Fig. 10. 5-oxy-anthranilic acid $10 \mathrm{mg} / \mathrm{kg}$ was injected prior to the X-ray and the diet.

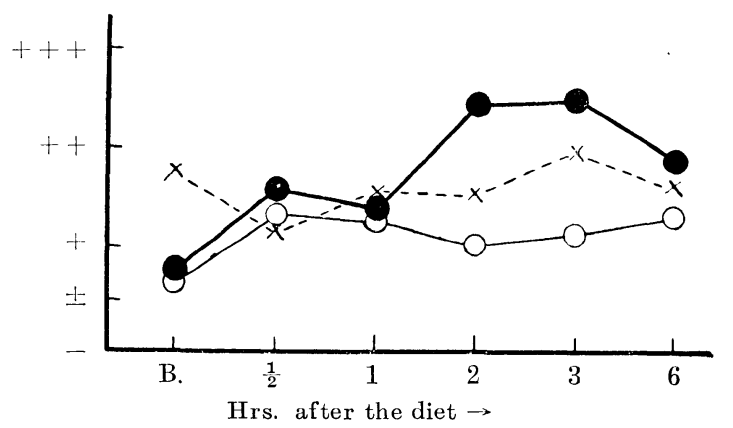

Fig. 11. 5-oxy-anthranilic acid $100 \mathrm{mg} / \mathrm{kg}$ was injected prior to the $\mathrm{X}$-ray and the diet.

tion of productin secretion caused by the X-ray seems to be minimized. In the chief cells, secretory granules and vacuoles are lesser than those of the normal case but production and discharge of the granules seem to be balanced in the cells. The secretion of the gastric juice, therefore, may be almost normal.

\section{Summary.}

The effects of X-ray radiation with a dose of $500 \mathrm{r}$ on the secretory activity of the gastric chief cells of rats were studied. The results are summarized as follows.

1. The effects of X-ray radiation on the secretory activity of the gastric chief cells have no connection with areas exposed.

2. The secretory activity of the chief cells, viz. production and discharge of secretory granules decreases positively after the irradiation.

3. The discharge of the histamine-like gastric hormone productin (FUJIE) from the gastric surface cells is slightly less after the X-ray.

4. These changes are a little more mild in the animals receiving daily $100 \mathrm{r}$ for 5 days than in the animals receiving a single dose of $500 \mathrm{r}$.

5. The effect of histamine on the secretory activity of the chief cells decreases and the effect of the decomposed product of histamine increases, if injected subcutaneously prior to the X-ray irradiation. 
These findings suggest that the hypofunction of the gastric chief cells induced by $\mathrm{X}$-ray radiation is attributable to the fact that the action of the discharged gastric hormone productin is inhibited by a certain substance which might have been produced in the tissue irradiated.

6. The protective effects of polyvinylpyrrolidon, thioctic acid and 5-oxy-anthranilic acid on the X-ray injury in the gastric chief cells are found to be not so remarkable. Only some of the functional derangements in the chief cells are slowed up by the use of these agents.

\section{内 容 自 抄}

$\mathrm{X}$ 線宿酔症候の最む主なるものが骨の症状であることに着眼し，500 r 程度の $\mathrm{X}$ 線が䏴腺主細胞分泌機能に及ぼす影響を腺細胞の機能的状態から推繁した。得 たる結果は以下の如く要約される。

1.X線の盟腺主細胞に及ぼす影響は筒に照射すると否とに测係なく姴われる。

2. 筒脉主細胞に於ける分泌機能即ち分泌顆粒の粕生及びその放出は薯明に抑 制される。

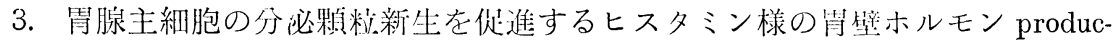
tin (藤江) の昌粘膜袁在細胞からの放出が軽度に抑制される。

4. $100 \mathrm{r}$ ずつ 5 日間に分制照射すると $500 \mathrm{r}$ を一時に照射する堤合よりもと れ等の抑制の程度はやや軽い.

5.ヒスタミンを皮下注射した後 X 線照射を行うとヒスタミンの胃腺主細胞分 泌機能に及ぼす效果が娍罗し，ヒスタミン分解産物の效晨がやや多く现われる。

以上の諸絬些加ら X 線による胃腺主細胞の機能低下は， X 線照射部位に産生さ れるであろう処の物質が等壁ホルモン productin の作用に阻害的に影響する絬果 であると碓信される。

$\mathrm{X}$ 線障碍防御剂として用いられている polyvinylpyrrolidon (pereston- $\mathrm{N}$ ), thioctic acid，5-oxy-anthranilic acid を恰索した処，いずれもX線の符線主細胞に及ぼ す影響を著明に軽減することは出来ないことが知られた。この埸合主細胞折見か

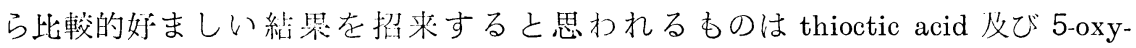
anthranilic acid である.

\section{References.}

Hirata, M.: Serological studies on the effect of X-ray irradiation on living body. (Fundamental studies of X-ray intoxication). (Jap. with Engl. abstr.) Nippon Acta radiol. 14 (1954). - Mayama, S.: Serochemical study on the irradiation of X-ray on the stomach. (Jap.) Nippon Acta radiol. 11 (1951). - Miyazaki, T. et al.: An experimental study of some chemicals as protective agents against radiation injury. (Jap. with Engl. abstr.) J. Wakayama Med. Soc. 10 (1959). - Nakamura, Z.: On the determination of histamine. (Jap.) Igakukenkyu 12 (1928). - Nakamura, J. et al.: A study on the later radiation 
injury. (Jap.) J. Wakayama Med. Soc. 8 (1957). - Shimizu, S.: Studies on the effects of histamine upon the secretory function of the gastric gland cells. Arch. hist. jap. 15(1958), 16 (1959). 